\title{
The effect of Ti additions on the hydrogen absorption properties of mechanically alloyed $\mathrm{Mg}_{2} \mathrm{Ni}$ powders
}

\author{
C.K. Lin ${ }^{\mathrm{a}, *}$, C.K. Wang ${ }^{\text {a }}$, P.Y. Lee $^{\text {b }}$, H.C. Lin ${ }^{\mathrm{c}}$, K.M. Lin ${ }^{\mathrm{a}}$ \\ ${ }^{a}$ Department of Materials Science and Engineering, Feng Chia University, Taichung 407, Taiwan, ROC \\ ${ }^{\mathrm{b}}$ Institute of Materials Engineering, National Taiwan Ocean University, Keelung 202, Taiwan, ROC \\ ${ }^{c}$ Department of Materials Science and Engineering, National Taiwan University, Taipei 106, Taiwan, ROC
}

Received 23 August 2005; received in revised form 30 November 2005; accepted 15 February 2006

\begin{abstract}
In the present study, mechanical alloying technique was used to prepare $\left(\mathrm{Mg}_{2} \mathrm{Ni}\right)_{100-x} \mathrm{Ti}_{x}(x=0,2.5,5,7.5$, and 10 wt.\%) powders starting from elemental powder mixture under an Ar atmosphere. The experimental results showed that the absorbed hydrogen content and reversible hydrogen content was 3.14 and $2.40 \mathrm{wt} . \%$ for $15 \mathrm{~h}$ milled $\mathrm{Mg}_{2} \mathrm{Ni}$ powders, respectively. The maximum hydrogen absorption content was increased to over $3.8 \mathrm{wt} . \%$ with $\mathrm{Ti}$ additions. The reversible hydrogen content also increased significantly (18-25\%) with Ti additions. Meanwhile, $15 \mathrm{~h}$ milled $\mathrm{Mg}_{2} \mathrm{Ni}-\mathrm{Ti}$ powders can absorb more than $3 \mathrm{wt} . \%$ of hydrogen within $1000 \mathrm{~s}$. Not only the hydrogen absorption ability but the hydrogen absorption rate were improved by the additions of titanium and MA treatment in $\mathrm{Mg}_{2} \mathrm{Ni}$ alloy.
\end{abstract}

(C) 2006 Elsevier B.V. All rights reserved.

Keywords: Mechanical alloying; Hydrogen absorption; $\mathrm{Mg}_{2} \mathrm{Ni}$; X-ray absorption

\section{Introduction}

Considerable effort has been concentrated on the hydrogen technologies from the energy and environmental point of view. The major techniques for hydrogen storage include to develop compressed high-pressure gas cylinder, condensation into liquid or even solid hydrogen, hydrogen absorption on large-surfacearea solids such as carbon nanotubes, and metal hydrides [1]. Among those, hydrogen storage by metal hydrides has attracted R\&D interests due to the lighter weight, higher hydrogen absorption percentage, and relatively low cost. Metal hydrides can also be used in many other applications such as purification, hydride heat pump, transportation, nickel/metal hydride batteries, etc. $[2,3]$.

Metal hydrides for hydrogen storage can be classified into various groups including $\mathrm{AB}, \mathrm{AB}_{2}, \mathrm{~A}_{2} \mathrm{~B}$, and $\mathrm{AB}_{5}$ [4]. $\mathrm{A}_{2} \mathrm{~B}$ type $\mathrm{Mg}_{2} \mathrm{Ni}$ with its high hydrogen content up to $3.6 \mathrm{wt} . \%$ is a potential candidate for practical application. The low hydriding/dehydriding rate, however, limits its practical application. Mechanical alloying (MA) process has been used successfully to

\footnotetext{
* Corresponding author. Tel.: +886 4 24517250x5309; fax: +886 424510014. E-mail address: cklin@fcu.edu.tw (C.K. Lin).
}

prepare metal hydrides [5-7]. By mechanically grinding starting materials, not only the grain size can be reduced but the defect concentration increases. Thus hydrogen absorption properties can be improved. For instance, Zaluski et al. [8] have improved the hydrogen absorption performance of $\mathrm{Mg}_{2} \mathrm{Ni}$ by MA. In the present study, we intend to improve further the $\mathrm{Mg}_{2} \mathrm{Ni}$ alloy by adding reactive Ti elements. MA technique was used to prepare $\mathrm{Mg}_{2} \mathrm{Ni}-\mathrm{Ti}$ alloy powders. The structure and hydrogen absorption properties of as-milled powders were investigated.

\section{Experimental}

Elemental powders of $\mathrm{Mg}(99.8 \%,<50$ mesh), $\mathrm{Ni}(99.98 \%$, $<300$ mesh) and Ti $(99.7 \%,<100$ mesh) were weighed to yield the desired compositions: $\left(\mathrm{Mg}_{2} \mathrm{Ni}\right)_{100-x} \mathrm{Ti}_{x}(x=0,2.5,5,7.5$, and 10), and then canned into an SKH 9 high speed steel vial together with $\mathrm{Cr}$ steel balls $(7 \mathrm{~mm}$ in diameter with ball-topowder ratio $=5: 1$ ) under an argon-filled glove box, where a SPEX 8000D shaker ball mill was used for MA. The overall process lasted $15 \mathrm{~h}$ and were interrupted every $15 \mathrm{~min}$ for the first hour and every 30 min thereafter. Each interruption was followed by an equal length of time $(\sim 30 \mathrm{~min}$.) to cool down the vials. The milling status was examined by using $\mathrm{X}$-ray diffraction and synchrotron X-ray absorption techniques. The 
X-ray analysis was performed using a Siemens D-5000 diffractometer ( $\mathrm{Cu} \mathrm{K} \alpha$ radiation). X-ray absorption spectroscopy measurements [9] were performed at the Wiggler-C beamline of the National Synchrotron Radiation Research Center (NSRRC) in Hsinchu, Taiwan. The hydrogen absorption properties of $15 \mathrm{~h}$ as-milled $\left(\mathrm{Mg}_{2} \mathrm{Ni}\right)_{100-x} \mathrm{Ti}_{x}$ powders were evaluated by pressure-composition-temperature (PCT) measurements, differential scanning calorimetry, and thermo-gravimetry analysis (SDT2960 Simultaneous DSC-TGA, TA Instrument). The PCT measurements were performed at $350^{\circ} \mathrm{C}$, while DSC/TGA measurements were performed under an $\mathrm{Ar}$ atmosphere at a heating rate of $5^{\circ} \mathrm{C} / \mathrm{min}$.

\section{Results and discussion}

\subsection{Structural characterization}

Fig. 1a shows the $\mathrm{X}$-ray diffraction patterns of the as-milled $\mathrm{Mg}_{2} \mathrm{Ni}$ powders with various milling times. Crystalline $\mathrm{Mg}$ and $\mathrm{Ni}$ diffraction peaks were observed at the early stage of milling and the peak intensities decreased gradually with increasing milling time. Formation of $\mathrm{Mg}_{2} \mathrm{Ni}$ phase can be noticed after $4 \mathrm{~h}$ of milling treatment. $\mathrm{Mg}_{2} \mathrm{Ni}$ phase with $\mathrm{Mg}$ and $\mathrm{Ni}$ solid solutions were obtained after $5 \mathrm{~h}$ of MA processing. Grain size reduction and/or residual strain arose from the MA treatment induced observable peak broadening. It is also interesting to note that the relative amount of $\mathrm{Mg}_{2} \mathrm{Ni}, \mathrm{Mg}$, and $\mathrm{Ni}$ phases varied with prolonged milling (compared the XRD patterns of 5, 10, and $15 \mathrm{~h}$ ) [10]. The addition of Ti elements influences the structural evolution during MA. The formation of $\mathrm{Mg}_{2} \mathrm{Ni}$ phase was delayed to a milling time of $5 \mathrm{~h}$ or more. For instance, the XRD patterns of as-milled $\left(\mathrm{Mg}_{2} \mathrm{Ni}\right)_{95} \mathrm{Ti}_{5}$ alloy powders was shown in Fig. 1b, where only limited $\mathrm{Mg}_{2} \mathrm{Ni}$ peak can be observed after $5 \mathrm{~h}$ of milling treatment. A similar trend was observed at the other compositions $(\mathrm{Ti}=2.5,7.5$ and 10 at.\%). It was thought

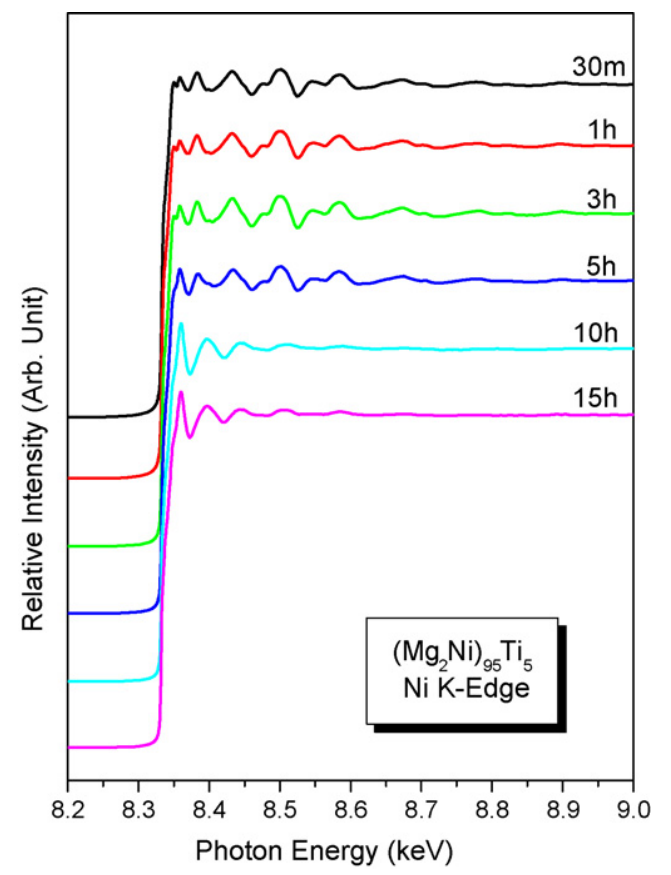

Fig. 2. Ni K edge absorption spectra for $\left(\mathrm{Mg}_{2} \mathrm{Ni}\right)_{95} \mathrm{Ti}_{5}$ powders with respect to the milling time.

that Ti elements were dissolved into $\mathrm{Mg}_{2} \mathrm{Ni}$ matrix and the $15 \mathrm{~h}$ milled $\left(\mathrm{Mg}_{2} \mathrm{Ni}\right)_{100-x} \mathrm{Ti}_{x}$ alloy powders were consisted of different ratios of $\mathrm{Mg}_{2} \mathrm{Ni}, \mathrm{Mg}$, and $\mathrm{Ni}$ solid solutions.

Except the long range order revealed by the X-ray diffraction technique, extended X-ray absorption fine structure (i.e., EXAFS) technique was used to investigate the local atomic change during MA. EXAFS spectra (Ni K edge, $8333 \mathrm{eV}$ ) of the as-milled $\left(\mathrm{Mg}_{2} \mathrm{Ni}\right)_{95} \mathrm{Ti}_{5}$ alloy powders as a function of milling time are shown in Fig. 2. Similar trend can be observed for as-milled $\mathrm{Mg}_{2} \mathrm{Ni}$ powders. It can be noted that EXAFS spectra for those at the early stage of milling (up to $3 \mathrm{~h}$ of milling)
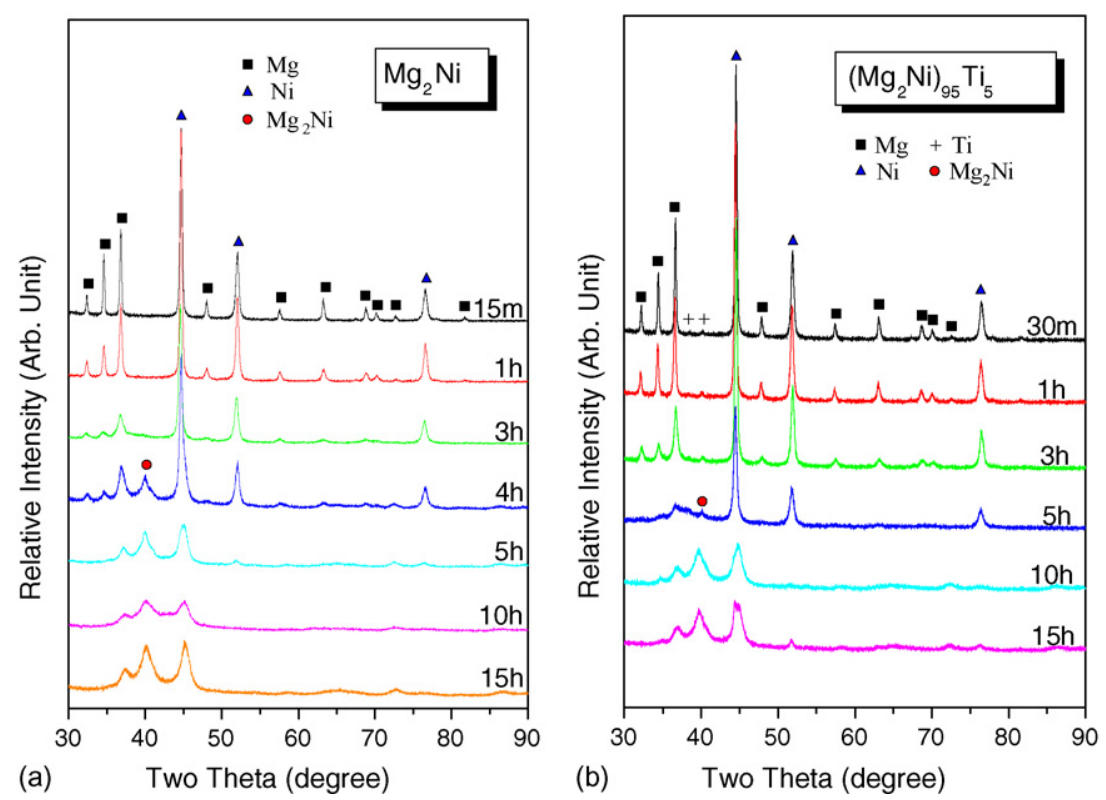

Fig. 1. X-ray diffraction patterns of (a) $\mathrm{Mg}_{2} \mathrm{Ni}$ and (b) $\left(\mathrm{Mg}_{2} \mathrm{Ni}\right)_{95} \mathrm{Ti}_{5}$ powders as a function of milling time. 

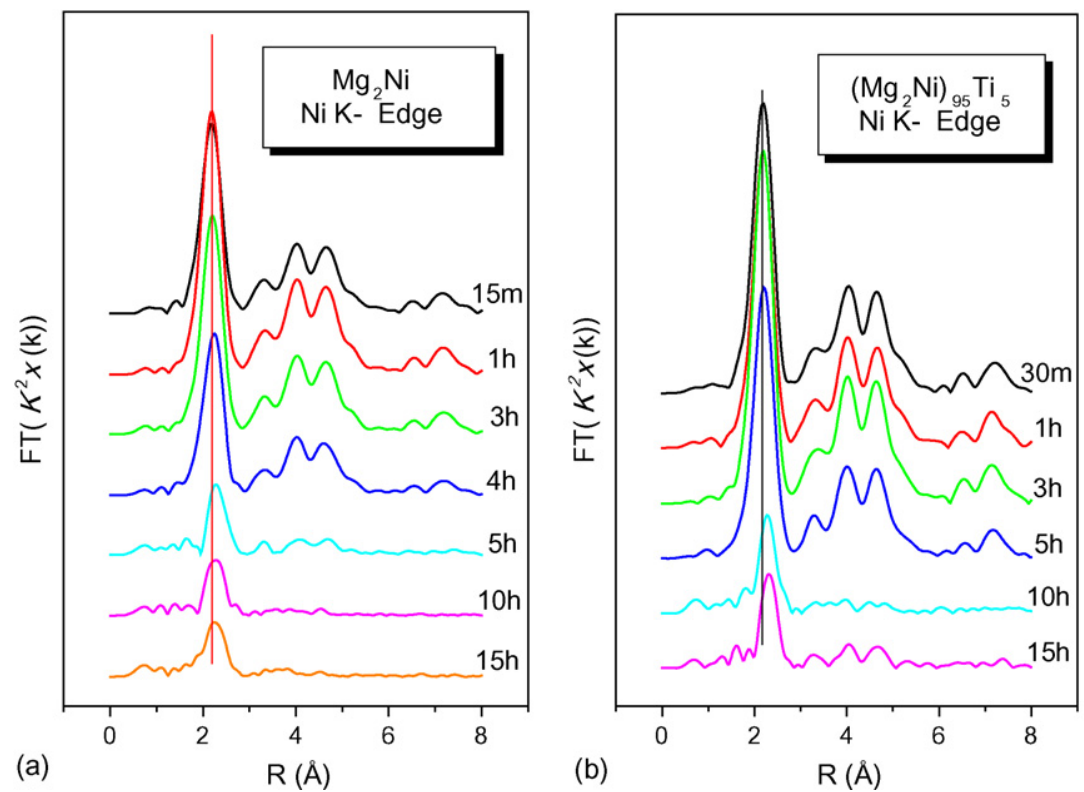

Fig. 3. Radial distribution functions for (a) $\mathrm{Mg}_{2} \mathrm{Ni}$ and (b) $\left(\mathrm{Mg}_{2} \mathrm{Ni}_{95} \mathrm{Ti}_{5}\right.$ powders with milling time.

exhibited no significant change. The EXAFS spectrum of $10 \mathrm{~h}$ milled powders was different from that of $3 \mathrm{~h}$ one, while $5 \mathrm{~h}$ spectrum is the transient stage. The radial distribution function (RDF) of the local atomic environment of detected atom (i.e., Ni) can be determined after Fourier transformation [9]. Fig. 3 shows the RDFs for $\mathrm{Mg}_{2} \mathrm{Ni}$ and $\left(\mathrm{Mg}_{2} \mathrm{Ni}\right)_{95} \mathrm{Ti}_{5}$ as-milled powders. The magnitudes of the RDF indicate the coordination numbers of detected atom at various distances. Similar RDFs can be observed at the early stage of milling ( 3 and $5 \mathrm{~h}$ for $\mathrm{Mg}_{2} \mathrm{Ni}$ and $\left(\mathrm{Mg}_{2} \mathrm{Ni}\right)_{95} \mathrm{Ti}_{5}$, respectively). This indicates that the face-centered cubic structure of $\mathrm{Ni}$ persisted at the early stage of milling. Significant decrease in the high order peaks can be observed when the as-milled powders consisted of a mixture of $\mathrm{Mg}_{2} \mathrm{Ni}, \mathrm{Mg}$, and $\mathrm{Ni}$ solid solutions, i.e., 5 and $10 \mathrm{~h}$ milling for $\mathrm{Mg}_{2} \mathrm{Ni}$ and $\left(\mathrm{Mg}_{2} \mathrm{Ni}\right)_{95} \mathrm{Ti}_{5}$, respectively. A slight increase of the nearest neighbor bond-length can be noted and $\left(\mathrm{Mg}_{2} \mathrm{Ni}_{95}\right)_{5} \mathrm{Ti}_{5}$ powders exhibited a larger increase than that of $\mathrm{Mg}_{2} \mathrm{Ni}$ powders. The addition of Ti elements not only postponed the formation of $\mathrm{Mg}_{2} \mathrm{Ni}$ phase but expanded the nearest bond length of $\mathrm{Ni}$.

$\mathrm{X}$-ray absorption near edge structure (XANES) of Ti K edge for those of $\left(\mathrm{Mg}_{2} \mathrm{Ni}\right)_{95} \mathrm{Ti}_{5}$ powders was also investigated to reveal the electronic structure change during MA. Fig. 4 shows the XANES spectra of $\left(\mathrm{Mg}_{2} \mathrm{Ni}_{95}\right)_{5} \mathrm{Ti}_{5}$ as-milled powders. The pre-edge structure of Ti exhibited (the arrow in Fig. 4) at the early milling stage (before $5 \mathrm{~h}$ of milling). Slight difference for $5 \mathrm{~h}$ milled powders can be observed when compared with those milled less than $3 \mathrm{~h}$. Pre-edge peak disappeared after $10 \mathrm{~h}$ milling. XANES spectra showed that Ti elements within the $5 \mathrm{~h}$ milled $\left(\mathrm{Mg}_{2} \mathrm{Ni}\right)_{95} \mathrm{Ti}_{5}$ powders persisted its electronic structure and changed with $10 \mathrm{~h}$ milling. Investigations by synchrotron $\mathrm{X}$-ray absorption spectroscopy technique suggested that the $\left(\mathrm{Mg}_{2} \mathrm{Ni}\right)_{95} \mathrm{Ti}_{5}$ alloy powders exhibited elemental characteristics of $\mathrm{Ni}$ and Ti even after $5 \mathrm{~h}$ of milling treatment. While $5 \mathrm{~h}$ milled $\mathrm{Mg}_{2} \mathrm{Ni}$ alloy powders, without Ti additions, exhibited a mixture of $\mathrm{Mg}_{2} \mathrm{Ni}, \mathrm{Mg}$, and Ni solid solutions.

\subsection{Hydrogen absorption properties}

The PCT measurements of $\left(\mathrm{Mg}_{2} \mathrm{Ni}\right)_{100-x} \mathrm{Ti}_{x}$ milled powders for $15 \mathrm{~h}$ were performed at $350^{\circ} \mathrm{C}$. As shown in Fig. 5a, the absorbed hydrogen content and reversible hydrogen content for $\mathrm{Mg}_{2} \mathrm{Ni} 15 \mathrm{~h}$ milled powders was 3.14 and $2.40 \mathrm{wt} . \%$, respectively. The hydrogen absorption properties can be improved significantly with the additions of Ti elements (only $\left(\mathrm{Mg}_{2} \mathrm{Ni}\right)_{95} \mathrm{Ti}_{5}$ was shown to avoid data overlap). The hydrogen content reached $3.84,3.88,3.82$ and 3.81 with $2.5,5,7.5$, and $10 \%$ Ti additions, respectively. Meanwhile, the reversible hydrogen content also

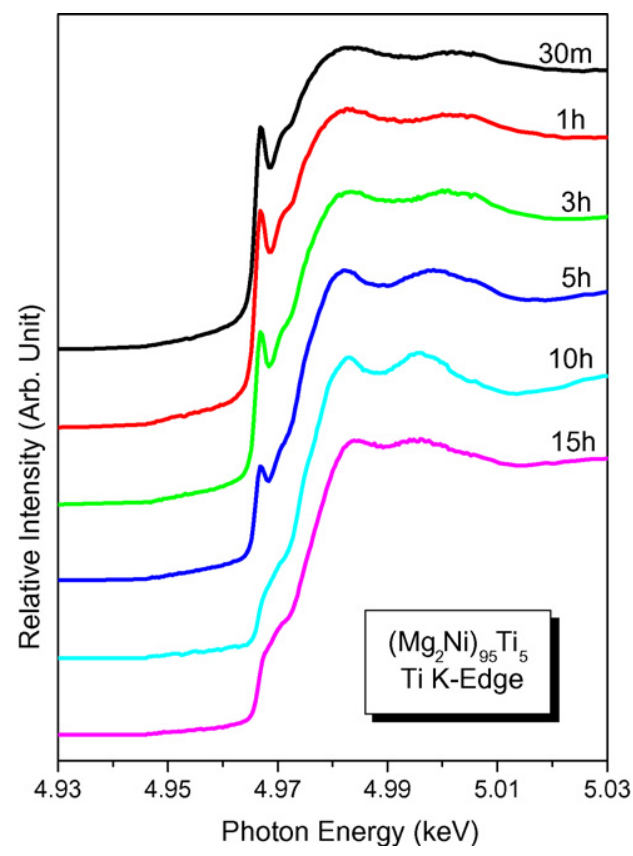

Fig. 4. Ti K edge absorption spectra for $\left(\mathrm{Mg}_{2} \mathrm{Ni}_{9}\right)_{95} \mathrm{Ti}_{5}$ powders with milling time. 

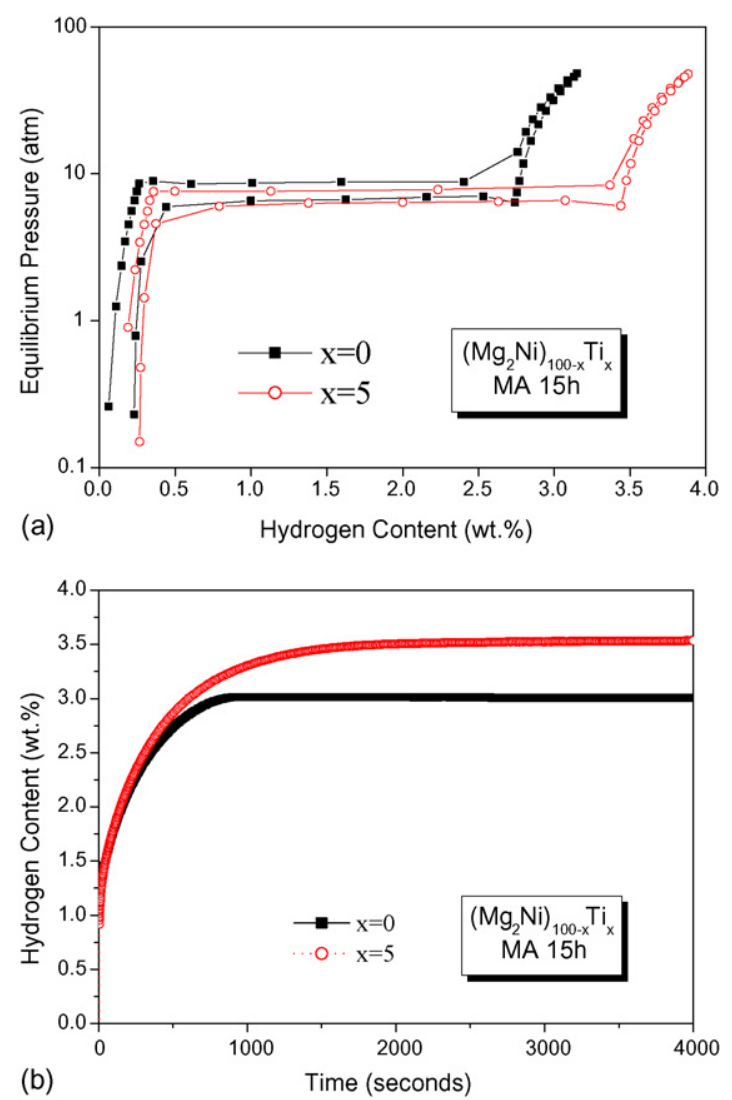

Fig. 5. (a) $\mathrm{P}-\mathrm{C}-\mathrm{T}$ and (b) kinetic curves for $15 \mathrm{~h}$ as-milled $\mathrm{Mg}_{2} \mathrm{Ni}$ and $\left(\mathrm{Mg}_{2} \mathrm{Ni}\right)_{95} \mathrm{Ti}_{5}$ powders.

increased (from 2.4 wt. $\%$ for $\mathrm{Mg}_{2} \mathrm{Ni}$ ) to 2.93, 3.01, 2.93, and $2.84 \mathrm{wt} . \%$, respectively. It is suspected that the addition of Ti elements expanding the lattice structure may be attributed to the improvement of hydrogen absorption properties.

In Fig. 5a, it is also noted that the slope within the plateau region approached zero. Orimo et al. [11] have reported that this slope is related to the energy for hydrogen atom diffusion into the interstitial sites within the $\mathrm{Mg}_{2} \mathrm{Ni}$ or $\mathrm{Mg}_{2} \mathrm{Ni}-\mathrm{Ti}$ lattices. Though MA process commonly induced high lattice strain, the hydriding at a temperature over $300^{\circ} \mathrm{C}$ can eliminate the induced strain. The flat slope within the plateau region for $15 \mathrm{~h}$ as-milled $\mathrm{Mg}_{2} \mathrm{Ni}-\mathrm{Ti}$ powders indicated that hydrogen atom can diffuse into alloy powders without overwhelming a large energy barrier.

Fig. $5 \mathrm{~b}$ shows the kinetic curves for $15 \mathrm{~h}$ as-milled $\mathrm{Mg}_{2} \mathrm{Ni}-\mathrm{Ti}$ powders. It can be noted that a significant improvement of hydrogen absorption can be observed with the Ti additions, similar to that revealed by Fig. 5a. For all the compositions investigated, $15 \mathrm{~h}$ as-milled $\mathrm{Mg}_{2} \mathrm{Ni}-\mathrm{Ti}$ powders can absorb more than $3 \mathrm{wt} . \%$ of hydrogen ( $\sim 3.5 \%$ with Ti additions) within $1000 \mathrm{~s}$. This value is comparable to the value (3.4wt.\%) reported by Zaluski et al. [8] who also used MA technique to prepare nanocrystalline $\mathrm{Mg}_{2} \mathrm{Ni}$ powders. The differences may be attributed to the MA processing and/or PCT testing parameters.

Fig. 6 shows the TGA/DSC curves of $\mathrm{Mg}_{2} \mathrm{Ni}-\mathrm{Ti}$ powders. Hydrided $\mathrm{Mg}_{2} \mathrm{Ni}$ powders exhibited a dehydriding temperature of $220^{\circ} \mathrm{C}$, while no distinct dehydriding temperature can be
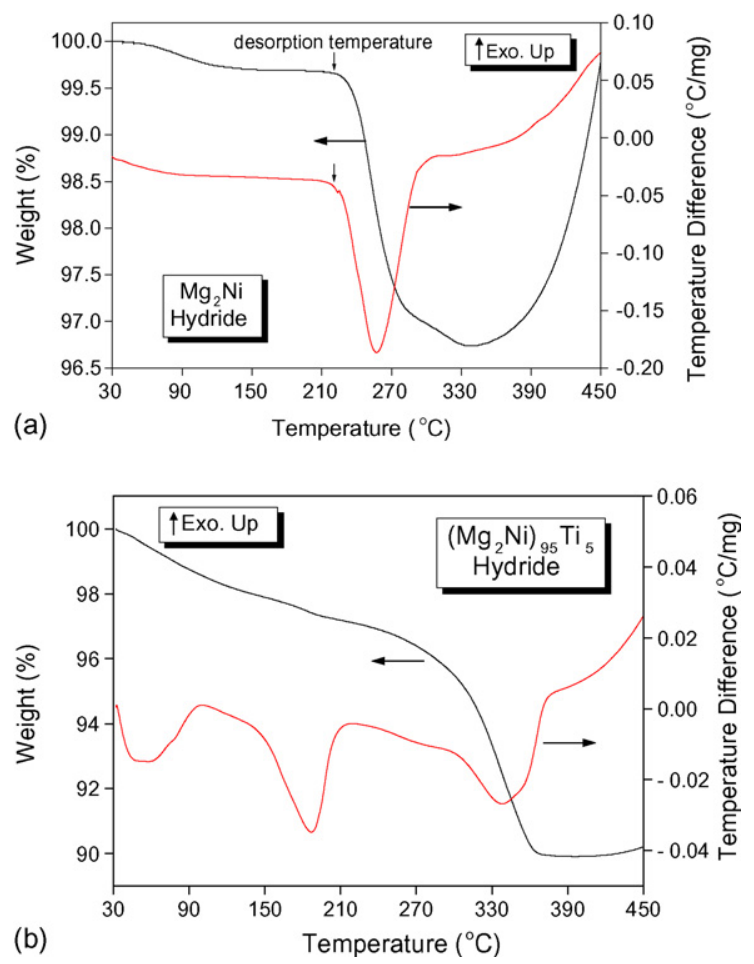

Fig. 6. TGA/DSC curves for hydrided (a) $\mathrm{Mg}_{2} \mathrm{Ni}$ and (b) $\left(\mathrm{Mg}_{2} \mathrm{Ni}_{95} \mathrm{Ti}_{5}\right.$ powders.

observed for $\left(\mathrm{Mg}_{2} \mathrm{Ni}\right)_{95} \mathrm{Ti}_{5}$ powders. Though not shown here, hydrided $\left(\mathrm{Mg}_{2} \mathrm{Ni}\right)_{92.5} \mathrm{Ti}_{7.5}$ and $\left(\mathrm{Mg}_{2} \mathrm{Ni}\right)_{90} \mathrm{Ti}_{10}$ powders exhibited a dehydriding temperature of 203 and $243{ }^{\circ} \mathrm{C}$, respectively. While with a limited Ti additions ( 2.5 or 5 at.\%), dehydriding behavior occurred over a wide temperature range. Fujii et al. [12] have reported that, during the hydriding of mechanically alloyed powders, hydrogen atoms may occupy the interstitial sites and the intergranular defects. Dehydriding may occur between intraand inter-grain regions. Therefore a decrease in the dehydriding temperature can be observed for mechanically alloyed powders [12].

In the present study, $\left(\mathrm{Mg}_{2} \mathrm{Ni}\right)_{92.5} \mathrm{Ti}_{7.5}$ powders exhibited a maximum and reversible hydrogen content of 3.82 and $2.93 \mathrm{wt} . \%$, respectively, while dehydrided at a relative low temperature of $203^{\circ} \mathrm{C}$. The overall hydrogen absorption properties can be improved with Ti additions.

\section{Summary}

Hydrogen absorption $\left(\mathrm{Mg}_{2} \mathrm{Ni}_{100-x} \mathrm{Ti}_{x}\right.$ alloy powders were synthesized by mechanical alloying. The $15 \mathrm{~h}$ milled $\left(\mathrm{Mg}_{2} \mathrm{Ni}\right)_{100-x} \mathrm{Ti}_{x}$ powders exhibited a mixture of $\mathrm{Mg}_{2} \mathrm{Ni}, \mathrm{Mg}$, and $\mathrm{Ni}$ solid solutions. The $15 \mathrm{~h}$ milled $\mathrm{Mg}_{2} \mathrm{Ni}$ powders exhibited a maximum and reversible hydrogen content of 3.14 and $2.40 \mathrm{wt} . \%$, respectively. The maximum hydrogen absorption content increased from $3.14 \mathrm{wt} . \%$ to a value larger than $3.8 \mathrm{wt} . \%$ with Ti additions. Reversible hydrogen content improved from $2.40 \mathrm{wt} . \%$ for $\mathrm{Mg}_{2} \mathrm{Ni}$ powders to $2.93,3.01,2.93$, and $2.84 \mathrm{wt} . \%$ with $2.5,5,7.5$, and $10 \% \mathrm{Ti}$ additions, respectively. The dehydriding temperatures also decreased from $220^{\circ} \mathrm{C}$ for $\mathrm{Mg}_{2} \mathrm{Ni}$ to 
$203^{\circ} \mathrm{C}$ for $\left(\mathrm{Mg}_{2} \mathrm{Ni}\right)_{92.5} \mathrm{Ti}_{7.5}$ powders. The additions of titanium and MA treatment did improve the hydrogen absorption properties of $\mathrm{Mg}_{2} \mathrm{Ni}$ alloy.

\section{Acknowledgements}

This project was funded by Feng Chia University Distinguished Research Program (FCU-93GB27). The entire staff at NSRRC were also thanked.

\section{References}

[1] J. Huot, in: H.S. Nalwa (Ed.), Nanoclusteres and Nanocrystals, American Scientific Publishers, Stevenson Ranch, 2003, p. 53.
[2] Q.D. Wang, C.P. Chen, Y.Q. Lei, J. Alloys Compd. 629 (1997) 253.

[3] V. Güther, A. Otto, J. Alloys Compd. 889 (1999) 293.

[4] L. Schlapbach, A. Züttel, Nature 414 (2001) 23.

[5] C. Suryanarayana, Int. Mater. Rev. 40 (1995) 41.

[6] M. Abdellaoui, D. Cracco, A. Percheron-Guegan, J. Alloys Compd. 293-295 (1999) 501

[7] R. Schulz, J. Huot, G. Liang, S. Boily, G. Lalande, M.C. Denis, J.P. Dodelet, Mater. Sci. Eng. A267 (1999) 240.

[8] L. Zaluski, A. Zaluski, J.O. Ström-Olsen, J. Alloys Compd. 217 (1995) 245.

[9] C.K. Lin, P.Y. Lee, J.L. Yang, C.Y. Tung, N.F. Cheng, Y. Hwu, J. Non-Cryst. Solids 232-234 (1998) 520.

[10] L. Aymard, M. Ichitsubo, K. Uchida, E. Sekreta, F. Ikazaki, J. Alloys Compd. 259 (1997) L5.

[11] S. Orimo, H. Fujii, Appl. Phys. A 72 (2001) 167.

[12] H. Fujii, S. Orimo, K. Ikeda, J. Alloys Compd. 253-254 (1999) 80. 